\title{
IMPLEMENTASI PEMBANGUNAN DESA PULAU PADANG KECAMATAN SINGINGI KABUPATEN KUANTAN SINGINGI
}

\author{
Sahri Muharam ${ }^{1}$ dan Emilia Emharis ${ }^{2}$ \\ ${ }^{1}$ Program Studi Administrasi Negara, Fakultas Ilmu Sosial, Universitas Islam Kuantan Singingi, Indonesia \\ muharamsahri21@gmail.com \\ ${ }^{2}$ Program Studi Administrasi Negara, Fakultas Ilmu Sosial, Universitas Islam Kuantan Singingi, Indonesia \\ harisyuspalira@yahoo.com
}

\begin{abstract}
Abstrak
Berdasarkan konsepsi pemerintahan daerah yang tertuang dalam Undang-Undang Dasar 1945 pada Pasal 18 menyatakan bahwa "Pembagian daerah Indonesia atas daerah besar dan kecil dengan bentuk susunan pemerintahannya ditetapkan dengan Undang-undang". Sedangkan pemerintahan desa tertuang dalam Undang-undang No. 23 Tahun 2014 adalah merupakan subsistem dalam sistem penyelenggaraan pemerintahan nasional, sehingga Desa memiliki kewenangan untuk mengatur dan mengurus kepentingan masyarakatnya, hal ini bermakna bahwa pemerintahan desa mendapat perhatian serius dalam membina masyarakat Desa. Desa yang merupakan satu kesatuan masyarakat hukum yang memiliki kewenangan untuk menaatur dan mengurus kepentingan masyarakat seternpat berdasarkan asal-usul dan adat istiadat setempat yang diakui dalam sistem pemerintahan nasional dan berada di daerah Kabupaten.Desa pulau padang telah melaksakan pembangunan jalan maupun pengadaan ATK untuk memudakan masyarakat mengurus Aministrasi.minim angaran pembangunan berdampak langsung kepada masyarakat.

Kata kunci: tekat, pembangunan, implementasi.
\end{abstract}

\begin{abstract}
Based on the conception of regional government as stated in the 1945 Constitution in Article 18 states that "The division of Indonesian territory over large and small areas with the form of government structure is established by law". While the village administration is contained in Law no. 23 Year 2014 is a subsystem in the system of national governance, so that the Village has the authority to regulate and manage the interests of the community, it means that the village government gets serious attention in fostering the village community. The village which is a unit of law community which has the authority to observe and manage the interests of the community based on the origin and local customs that are recognized in the national government system and are in the area of the Regency. The island of Padang has implemented the road construction and the procurement of ATK to enslave the community take care of Aministrasiminim development of development directly affects the community.

Keywords: sticky, development, implementation.
\end{abstract}




\section{PENDAHULUAN}

Kehadiran Undang-undang nomor 23 Tahun 2014 sebagai batu penjuru penyelenggaraan desentralisasi dan otonomi daerah telah membawa berbagai perubahanperubahan.terhadap tatanan penyelenggaraan pemerintahan daerah. Undang-undang pada dasarnya pelimpahan kewenangan pusat kepada daerah bukan pelinpahan wewenang kepada pemerintah daerah sehingga penyelenggaraan pemerintahan di daerah selain peran eksekutif dan legislatif daerah harus pula mengikut sertakan peran masyarakat termasuk swasta. Titik berat pemberian otonomi kepada daerah adalah pemberdayaan dan meningkatkan kesejahteraan masayarakat bukan untuk pemberdayaan masyarakat.

Perangkat daerah berdasarkan undang-undang no 23 Tahun 2014 dan peraturan pemerintah nomor 47 tahun 2015 adalah organisasi/lembaga pada pemerintah yang terdiri atas sekretaris daerah dinas daerah, lembaga teknis daerah, Kecamatan, Kelurahan/Desa sesuai dengan kebutuhan daerah. Agar supaya perangkat daerah tersebut dapat menjalankan tugas pokok dan fungsi serta kewenangan yang dimilikinya secara epektif maka setiap perangkat daerah harus dipasilitasi minimal dengan dengan unsur 3P (pembiayaan, personel dan perlengkapan yang memadai sesuai dengan kebutuhannya masing-masing).

Pembinaan atas penyelenggaraan pemerintah daerah adalah upaya yang dilakukan pemerintah daerah dan atau gubernur selaku wakil pemerintah didaerah untuk mewujudkan tercapainya otonomi Daerah. Dalam rangka pembinaan oleh pemerintah, Menteri dan Pimpinan Lembaga Pemerintah non Departemen' melakukan Pembinaan sesuai dengan Fungsi dan kewenangan masing-masing yang dikoordinasikan oleh menteri dalam negeri untuk pembinaan pengawasan Provinsi serta oleh Gubernur Untuk Pembinaan dan pengawasan kabupaten/kota begitu pula dalam pembinaan dan pengawasan terhadap pemerintahan Desa maka kabupaten selaku pemerintahan tinggi yang melakukan penyelenggaraan atas pemerintahan Desa. Dalam penyelenggaraan pemerintahan desa Bupati/walikota dapat melimpahkan kepada Camat. Dengan demikian Camat selaku perangkat daerah Kabupaten berhak menyeelnggarakan pembinaan dan pengawasan terhadap pemerintahan Desa sesuai dengan teori yang dikemukakan oleh beberapa ahli tentang pembinaan diatas tadi. Pembinaan dan pengawasan Camat atas penyelenggaraan pemerintahan Desa adalah Proses kegitan yang ditujukan untuk menjamin agar Pemerintahan Desa berjalan sesuai dengan rencana dan ketentuan peraturan perundang-undangan yang 
berlaku.

Sejak diberlakukannya Undang-undang Republik Indonesia Nomor 22 Tahun 1999 sebelum dikeluarkannya Undang-undang Nomor 32 Tahun 2004 dan Undang-undang 23 tahun 2014 tentang Pemerintahan Daerah, masyarakat daerah khususnya masyarakat Desa telah menaruh harapan besar terhadap implementasi otonomi desa. Kehadiran otonomi daerah bagi setiap warga di Desa memberikan dinamika dan nuansa baru dalam proses penyelenggara pemerintahan Desa. Sebab masyarakat Desa sangat sadar bahwa keberadaan institusi demokrasi desa selama ini berada dalam posisi yang sangat tidak kondusif/efektif dalam mendorong penegakan demokrasi pada pemerintahan Desa.

Konsekuensi implementasi otonomi Desa, merupakan salah satu perubahan yang fundamental adalah Terjadinya pergeseran struktur pemeritahan pada pemerintahan Desa yang jauh berbeda dibanding sebelumnya. Angin segar yang dibawa arus oleh reformasi adalah lahirnya kelembagaan pemerintah ditingkat lokal/bawah (Desa) yang diharapkan mampu memberikan dinamika dan nuansa pemerintahan yang lebih Demokratis, Otonom, Independen dan sekaligus Prospektif dalam pengembangan demokrasi ditingkat Desa. Seiring diberlakukannya Undang-undang No. 23 Tahun 2014, adanya dampak khusus yang terlihat dalam proses penyelenggaraan Pemerintahan Desa yang jauh lebih berdaya guna dan dapat menegakkan prinsif-prinsif demokrasi adalah hadirnya dan dibentuknya Pemerintah Desa sebagai lembaga parlemen (legislatif) pada Pemerintahan Desa.

Kedudukan Desa dalam sistem pemerintahan di Indonesia merupakan unit Pemerintah terendah dan merupakan kesatuan dasar Negara. Dalam hal ini Desa :

a.Berhak dan berkewajiban mengatur dan mengurus rumah tangganya menurut adat kebiasaan setempat, peraturan negara, dan atau peraturan daerah yang berlaku.

b.Desa wajib melaksanakan tugas yang diberikan oleh pemerintah pusat dan daerah.

c.Untuk melaksanakan tugas tersebut Kepala Desa memperoleh sumbangan atau bantuan.Desa Pulau Padang dalam menjalan roda pemrintahan harus didukung sarana danprasarana yang memadai untuk itu dukungan dari Pemerintah yang diatasnya sangat dibutukan,Dalam kenyataan minim dukungan dari pemerintah dapat dilihat dari anggara yang ada.

Tabel 1 Jenis Kegiatan

\begin{tabular}{|l|l|l|}
\hline No & Jenis Kegiatan & Sumber Dana \\
\hline 1 & Semenisasi & APBN \\
\hline
\end{tabular}






Dana APBN Rp304.419.000

Dana APBD Rp 60.000.000

Pada tabel diatas dapat dilihat bahwa dana sumber Desa pada tahun 2015 digunakan dalam pememuham kebutuhan semenisasi desa dan ATK telah di laksanakan. Namun yang menjadi perhatian dalam pelaksanaan pembangunan tersebut adalah dinilai bahwa kurangnya perhatian pemerintah daerah kabupaten kuantan singing dan pemerintahan provinsi Riau dalam bidang pembangunan Desa.

Kepala Desa yang ada di Kabupaten Kuantan Singingipada umumnya dan Desa Pulau Padang pada khususnya untuk lebih meningkatkan pelaksanaan pembangunan fisik Desa dalam menciptakan dan mengelola desa secara maskimal. Dari dasar pemikiran dan gejala yang ditemukan diatas, peneliti berkeinginan untuk mengadakan penelitian yang berjudul “ Implementasi Program Pembangunan Desa Pulau Padang Kecamatan Singingi Kabupaten Kuantan Singingi”.

\section{MASALAH}

Desa merupakan suatu kesatuan masyarakat hukum yang memiliki kewenangan untuk mengatur dan mengurus kepentingan masyarakat setempat berdasarkan asal-usul dan adat istiadat setempat yang diakui dalam sistem pemerintahan nasional dan berada di daerah Kabupaten.

Pembangunan Desa yang dilakukan merupakan suatu proses kegiatan masyarakat dan pemerintah yang sama-sama berpartisipasi aktif dan dikelola oleh tingkat Desa, proses pembangunan yang merupakan suatu proses yang berjalan tanpa upaya yang disadari dan disengaja. Namun dalam pelaksanaan pembangunan Desa dan pemerintahan dinilai belum berjalan dengan baik.

Dalam pelaksanaan pembangunan Desa Pulau Padang masih belum maksimal karena perhatian pemerintahan daerah kurang, dilihat dari minimnya anggaran pembangunan yang di dapat. Sehingga dari permasalahan tersebut diangkat rumusan masalah dalam penelitian ini adalah "Bagaimanakah Implementasi Program Pembangunan Desa Pulau Padang Kecamatan Singingi Kabupaten Kuantan Singingi““ 


\section{TINJAUAN PUSTAKA}

\section{Konsep Pemerintahan}

Pemerintahan dapat diartikan sebagai badan atau lembaga-lembaga para penguasa sebagai pejabat pemerintah untuk melaksanakan kegiatan pemerintahan, pelaksanaan kegiatan pemerintah tersebut diharapkan menaati seluruh ketentuan hukum dalam batas wilayah negara, baik oleh setiap warga negara secara perseorangan maupun secara kolektif oleh setiap komponen pemerintahan maupun kemasyarakatan.

Apabila ditinjau dari defenisi pemerintah, maka pemerintah berasal dari kata pemerintah, yang paling sedikit kata "perintah" tersebut memiliki empat unsur yaitu : ada dua pihak yang terkandung, kedua pihak tersebut saling memiliki hubungan, pihak yang memerintah memiliki wewenang, dan pihak yang diperintah memiliki ketaatan.

Sedangkan konsep ilmu pemerintahan menurut H.A.Brasz mengemukakan bahwa ilmu pemerintahan dapat diartikan sebagai ilmu yang mempelajari tentang cara bagaimana lembaga pemerintahan umum itu disusun dan difungsikan baik secara ke dalam maupun keluar terhadap warganya.

Pemerintah adalah segala kegiatan yang terorganisir yang bersumber kepada kedaulatan dan kemerdekaan, berlandaskan dasar negara. Rakyat, penduduk dan wilayah suatu negara memiliki tujuan untuk mewujudkan negara berdasarkan konsep dasar negara. Selanjutnya konsep-konsep tercapainya negara dalam ilmu politik adalah negara, kekuasaan, pengambilan keputusan, kebijaksanaan dan pembagian, atau alokasi (Budiardjo, 2003)

Adapun tugas-tugas pokok pemerintahan adalah menjamin keamanan negara dari segala kemungkinan serangan dari luar, dan menjaga agar tidak terjadi pemberontakan dari dalam yang dapat menggulingkan pemerintah yang sah atau mengancam integritas negara melalui cara-cara kekerasan.

1. Memelihara ketertiban dengan mencegah terjadinya gontok-gontokan diantara warga masyarakat, menjamin agar perubahan apapun yang terjadi didalam masyarakat dapat berlangsung secara damai.

2. Menjamin diterapkannya perlakukan yang adil kepada setiap warga masyarakat tanpa membedakan status apapun yang melatar belakangi keberadaan mereka.

3. Melakukan pekerjaan umum dan memberi pelayanan dalam bidang-bidang yang tidak mungkin dikerjakan oleh lembaga non -pemerintah, atau yang akan lebih 
baik.

4. Melakukan upaya-upaya untuk meningkatkan kesejahteraan sosial.

5. Menerapkan kebijakan ekonomi yang menguntungkan masyarakat luas.

6. Menerapkan kebijakan untuk pemeliharaan sumber daya alam dan lingkungan hidup.

Dalam kehidupan masyarakat, tidak semua masyarakat dapat ikut serta dalammengurusdanmemenuhikebutuhan-kebutuhanbersama.Sehinggaberdasarkan hasil musyawarah secara bersama-sama, masyarakat memilih salah seorang dari mereka dan dengan kepercayaan penuh diberikanlah kewenangan kepadanya (pemimpin) untuk mengatur dan mengurus urusan rumah tangga negaranya. Hal ini tidak terlepas dari unsur terbentuknya sebuah negara, diantaranya ; adanya rakyat (masyarakat) tertentu, adanya daerah (wilayah) tertentu, adanya pemerintahan yang berdaulat dan mendapat pengakuan dari dunia internasional (Mahfud MD, 2001).

Rakyat merupakan syarat mutlak unsur suatu negara, maka dalam kehidupan bermasyarakat diatur oleh pihak yang berwenang dan memegang kekuasaan, pihak yang berwenang tersebut sering disebut dengan pemerintah, baik pemerintah pusat maupun pemerintah daerah.

Pemerintah adalah segala kegiatan yang terorganisir yang bersumber kepada kedaulatan dan kemerdekaan, berlandaskan dasar negara. Rakyat atau penduduk dan wilayah suatu negara memiliki tujuan untuk mewujudkan negara berdasarkan konsep dasar negara tersebut. Selanjutnya konsep-konsep tercapainya negara dalam ilmu politik adalah negara (state), kekuasaan (power), pengambilan keputusan (Decisionmaking), kebijaksanaan (policy, beleid) dan pembagian (Distribution), atau alokasi (Allocation).

Dengan demikian Negara merupakan alat yang mempunyai kekuasaan untuk mengatur hubungan-hubungan manusia dalam masyarakat, selain itu negara dalam suatu wilayah juga dapat memaksakan kekuasaannya secara sahterhadap golongan kekuasaan dengan menetapkan tujuan-tujuan dari kehidupan bersama. Negara sebagai organisasi akan membawa kearah dan tujuan yang telah ditetapkan oleh penguasanya. Pencapaian tujuan dilakukanlah pengendalian oleh pemerintah berdasarkan hukum, termasuk peraturan pemerintah daerah (Perda) beserta alat-alat perlengkapan pemerintahan lainnya (Situmorang, 1993; 7). 


\section{Konsep Pembangunan}

Selanjutnya dapat dilihat pengertian pembangunan. Dimana ada banyak pendapat para pakar ketenagakerjaan tentang pengertian pembangunan, namun meskipun dengan redaksi yang berbeda, pada umumnya kesemua pendapat para ahli tersebut mengandung kesamaan pengertian, yaitu pembangunan merupakan proses perubahan kedala yang lebih baik.

Pembangunan adalah suatu usaha atau rangkaian usaha pertumbuhan dan perubahan yang berencana dan dilakukan secara sadar oleh suatu bangsa, negara, pemerintah, menuju modernitas dalam rangka pembinaan bangsa.

Konsep pembangunan sekurang-kurangnya dapat mengandung empat arti yaitu :

1. Pembangunan sebagai kata tunggal memiliki makna majemuk.

2. Sebagai kata sifat pembangunan adalah kondisi yang lebih baik darikeadaan sebelumnya.

3. Sebagai kata benda pembangunan berkaitan dengan output atau hasildari suatu kegiatan.

4. Pembangunan sebagai kata kerja diartikan sebagai proses kegiatan yangberlangsung dalam jangka waktu panjang dan terus menerus.

Lebih jauh Sondang P. Siagian (2003) mengemukakan bahwa salah satu ide pokok yang menjadi dasar pembangunan yaitu : " pembangunan diharapkan bermuara pada suatu titik akhir tertentu seperti masalah keadilan sosial, kemakmuran yang merata, kesejahteraan material, mental spritual dan sebagainya. Sehingga dapat dilihat bahwa kondisi pembangunan yang baik adalah melihat pembangunan yang menyertakan kerjasama dengan pelaksanaan rencana yang matang dan akurat, pelaksanaan yang disesuaikan dengan reneana serta adanya pengawasan dalam pelaksanaan pembangunan.

\section{METODE PENELITIAN}

\section{Tipe Penelitian}

Di dalam mempermudah penulis dalam mengumpulkan data yang dibutuhkan dalam penelitian ini, metode yang akan digunakan adalah penelitian survey. Pengertian survei dibatasi pada penelitian yang datanya dikumpulkan dari sampel atas populasi untuk mewakili seluruh populasi. Dengan demikian penelitian survei secara komplik adalah " penelitian yang mengambil sampel dari satu populasi dengan menggunakan quessioner sebagai alat pengumpulan yang pokok. Dan penelitian survei ini akan menuntun sipeneliti dalam 
membuat daftar pertanyaan berupa quessioner yang dimaksud diatas untuk disebarkan kepada populasi yang sudah ditentukan.

\section{Lokasi Penelitian}

Lokasi penelitian ini dilakukan di Desa Pulau Padang pelaksanaan pembangunan desa dan pengembangan desa belum berjalan dengan baik.

Adapun alasan dipilihnya desa ini sebagai lokasi penelitian, karena dilihat dari perkembangan masyarakatnya yang cukup berkembang dengan baik dalam biografi (kependudukan), sosial, ekonomi, pendidikan dan pembangunan desa yang membutuhkan pembenahan yang sesuai dengan aspirasimasyarakat.

\section{Populasi Dan Sampel}

Adapun yang menjadi populasi penelitian ini adalah semua pihak yang dapat menilai Pelaksanaan Strategi Pembangunan Desa dari aparatur pemerintahan yaitu Kepala Desa, dan aparatur seperangkat Desa serta ditambah dengan unit masyarakat Desa.

Selanjutnya untuk mempermudah dalam pengelolaan data penelitian ini, maka populasi yang dijadikan sebagai responden. Adapun sampel yang diambil dari aparatur pemerintahan. Dalam hal penetapan sampel untuk aparat pemerintahan ini menggunakan metode sensus dengan pengertian bahwa seluruh populasi dijadikan responden.

\section{Teknik Penarikan Sampel}

Proses penarikan sampel dalam penelitian ini bertitik tolak pada jumlah populasi yang relatif cukup banyak, maka untuk memerlukan data yang dibutuhkan, diambil beberapa sampel dari setiap unsur populasi yang dirasa memungkinkan untuk mewakili setiap kelompok. Sehingga tekhnik penarikan sampel yang digunakan yaitu tekhnik penarikan dengan " porposive sampling".

\section{Data Dan Sumber Data}

1. Data Primer

Data primer adalah data yang diperoleh dari responden berupa :

a) Data tentang Pelaksanaan Strategi Pembangunan Desa Pulau Padang Kecamatan Singingi Kabupaten Kuantan Singingi.

b) Data tentang hambatan Pelaksanaan Strategi Pembangunan Desa Pulau Padang Kecamatan Singingi Kabupaten Kuantan Singingi.

2. Data Skunder 
Data skunder adalah data yang diperoleh dari instansi pemerintah yang ada hubungannya dengan penelitian ini yaitu:
a) Keadaan geografis danpenduduk.
b) Keadaan sosial ekonomi masyarakat
c) Tingkat pendidikan masyarakat
d) Keadaan sarana dan prasarana
e) Tugas dan fungsi pemerintahan Desa
f) Struktur organisasi pemerintah Desa

\section{Teknik Pengumpulan Data}

1. Wawancara, yaitu melakukan dialog / percakapan (tanya jawab) untuk memperoleh data secara langsung dari responden.

2. Observasi, yaitu untuk melengkapi data yang diperlukan, makadibutuhkan langsung kelapangan untuk melihat secara langsung upaya pemerintah dalam menggali potensi kepenghuluan.

3. Quesionere, yaitu untuk melengkapi data yang diperlukan, makadibutuhkan menyusun daftar pertanyaan beserta jawabannya yang diberikan kepada responden sebagai sampel terpilih

\section{Analysis Data Dan Penarikan Kesimpulan}

Setelah data diperoleh, baik berupa data primer maupun data sekunder,kemudian penulis klasifikasikan sesuai dengan permasalahan pokok yang diteliti, penulis sajikan dalam bentuk kalimat secara sistematis berdasarkan hasil analisis dari ketentuan hukum atau pendapat para ahli.

Penarikan kesimpulan dilakukan dengan secara induktif yaitu, penarikan kesimpulan dari hal-hal yang bersifat khusus kepada ketentuan peraturan dan perundang-undangan yang bersifat umum. Adapun yang dimaksud dengan hal-hal yang bersifat khusus adalah, khusus mengenai data-data tentang Pelaksanaan pembangunan di Desa Pulau Padang Kecamatan Singingi Kabupaten Kuantan Singingi kemudian dihubungkan dengan Pelaksanaan Pembangunan wisata. 


\section{PEMBAHASAN}

\section{Gambran Umum Lokasi Penelitan}

Pada ummnya iklim diwilayah Desa Pulau Padang dikenal dengan dua musim yaitu musim hujan dan musim kemarau, musim penghujan biasanya terjadi dalam bulan September sampai bulan Maret, sedangkan musim kemarau terjadi pada bulan April sampai bulan Agustus. Pada musim kemarau sering terjadi kekeringan, dimana sulit ntuk mendapatkan air bersih dari sumur penduduk, maka untuk mendapatkan air bersih penduduk harus memanfaatkan air sungai Singingi untuk mandi dan mencuci. Sedangkan musim kemarau terjadi pada bulan April sampai Agustus dengan temperatur sedang.

\section{Keadaan Penduduk}

Penduduk Desa Pulau Padang mayoritas beragama Islam. Berdasarkan data yang diperoleh di lokasi penelitian jumlah penduduk Desa Pulau Padang adalah 1133 jiwa, yang perlu juga diketahui keadaan jumlah penduduk yang ada ini sudah merupakan campuran antara suku-suku yang ada di Desa Pulau Padang tersebut.

Ditinjau dari segi mata pencaharian penduduk dimana kehidupan awalmasyarakat dengan kondisi alam yang lebih banyak mencari nafkah dari sektorpertanian dan nelayan. Di Desa Buluh Pulau Padang masyarakat juga bekerja sebagai pemotong karet,petani sawit, dagang dan Iain-lain.

\section{Tugas Dan Fungsi Kepala Desa}

Diatur dalam Keputusan Menteri Dalam Negeri Nomor 64 tahun 1999 tentang Pedoman Umum Pengaturan Mengenai Desa menyebutkan bahwa tugas dan kewajiban Kepala Desa adalah :

a. Memimpin penyelenggaraan pemerintah Desa.

b. Membina kehidupan masyarakat Desa.

c. Membina perekonomian Desa.

d. Mendamaikan perselisihan masyarkat Desa..

e. Memelihara ketentraman dan ketertiban masyarakat Desa.

f. Mewakili Desanya didalam dan diluar pengadilan dan dapat menunjuk kuasa hukumnya.

g. Mengajukan rancangan peraturan Desa dan bersama BPD/BPM menetapkan sebagai peraturan Desa.

h. Menjaga kelestarian adat istiadat yang hidup dan berkembang diDesa/marga 
yangbersangkutan.

\section{KEDUDUKAN, TUGAS DAN KEWAJIBAN KEPALA DESA}

Kepala Desa berkedudukan sebagai pemimpin dalam penyelenggaraan Pemerintah Desa berdasarkan kebijakan yang ditetapkan bersama Badan Perwakilan Desa.

\section{TUGAS PERANGKAT DESA}

Perangkat Desa bertugas membantu Kepala Desa terdiri dari unusur - unsur yang masing-masing bertugas sebagai berikut:

a. unsur staf memberikan pelayanan administrasi.

b. unsur pelaksana merupakan pelaksana teknis lapangan

c. unsur wilayah membantu Kepala Desa diwilayah bagian Desa yang disebut Kepala Dusun.

Hasil penelitian bahwa pembangunan di Desa pulau padang bejalan baik akan Tetapi pemiliharaan baik fisik maupun sarana dan prasana tidak dijaga dengan baik sehinga bangunan ada cepat rusak, untuk itu semua kompenan baik kepala desa beserta perankatnya maupun BPD dan anggota serta masyarakat secara umum ikut menjaga dan memeliharanya, Minim anggaran baik dari angaran desa,kabupaten,propinsi,maupun pusat sangat berdampak lansung kepada masyrakat,akses jembatan dan jalan sangat dibutukan oleh masyarat untuk membawa hasil panen baik kelapa sawit maupun karet beku masyarakat sanngat kesulitan dan butu biaya tinggi untuk membawa ke toke atau pengepul,diharapkan kedepan nya baik pemrintahan kabupaten, pemeritahan propinsi dan pemeritan pusat mendengar aspirasi masyarakat desa pulau padang khusus dan rakyat Indonesia secara umum sehingga tercapai rakyat yang sejahtera.

\section{KESIMPULAN}

Adapun kesimpulan dalam penelitian ini yang mengangkat judul Implementasi Program Pembangunan Desa Pulau Padang Kecamatan Singingi Kabupaten Kuantan Singingi dan mengenai Pelaksanaan Standart Pelayanan Publik Berdasarkan Pasal 21 Undang Undang No 23 tahun 2009 Tentang Pelayanan Publik Di Desa Pulau sebagai berikut:

1. Dalam pelaksanaan pembangunan desa Pulau Padang dinilai telah berjalan dengan baik, hal ini dapat diliaht dari pelaksanaan pembangunan dan semenisasii desa yang dinilai dari upaya pemerintah desa dalam meningkatkan sarana prasarana dalam pelaksanaan pembangunan desa. 
2. Dalam rangka Pelaksanaan Standart Pelayanan Publik Berdasarkan Pasal 21 Undang Undang No 25 Tahun 2009 Tentang Pelayanan Publik Di Desa Pulau Padang Kecamatan Singingi Kabupaten Kuantan Singingi.

3. Standart Pelayanan Publik berdasarkan Undang - undang No 25 tahun 2009 Tentang Pelayanan Publik sebagaimana yang tercantum dalam pasal 21 indikator sistem. Sistem / Mekanisme / Prosedur, Jangka / Waktu Penyelesaian, Biaya / Tarif dan Pelaksana yang terlaksana.

4. Untuk jangka waktu penyelesaian dilapangan masih banyak kendala - kendala terutama masalah waktu penyelesaian mencapai lebih dari waktu yang ditetapkan. Waktu yang ditentukan tidak cukup untuk melakukan penelitian.

5. Untuk pelaksanaan dimana telah dilakukan pendidikan, Pelatihan dan etika pegawai berjalan dengan baik. Namun untuk pendidikan dan pelatihan masih kurang dilaksanakan.

\section{DAFTAR PUSTAKA}

Budiardjo. Miriam. (2003). Dasar-Dasar Ilmu Politik. Jakarta: PT. Gramedia Pustaka Utama.

MD, Mahfud. (2001). Dasar-Dasar dan Struktur Ketatanegaraan Indonesia. Jakarta: Rineka Cipta.

Situmorang, Victor. (1993). Perdamaian dan Perwasitan Dalam Hukum Acara Perdata. Jakarta: Rineka Cipta.

Siagian, Sondang P. (2003). Administrasi pembangunan: konsep, dimensi, dan strateginya. Bumi Aksara.

Peraturan dan Perundang-udangan:

Undang-Undang Nomor 23 Tahun 2014

Undang-Undang Nomor 32 Tahun 2004 Tentang Pemerintahan Daerah

Peraturan pemerintah No. 72 Tahun 2005 Tentang Desa 